\title{
Li-Fraumeni-szindróma
}

\author{
Sejben Anita dr. ${ }^{1}$ - Tiszlavicz László dr. ${ }^{1}$ - Polyák Kornélia dr. ${ }^{6}$ \\ Kovács László dr. ${ }^{2}$. Maráz Anikó dr. ${ }^{3}$. Török Dóra dr. ${ }^{4}$ \\ Leprán Ádám dr. ${ }^{5}$. Ottlakán Aurél dr. ${ }^{5}$. Furák József dr. ${ }^{5}$
}

\author{
'Szegedi Tudományegyetem, Általános Orvostudományi Kar, Pathologiai Intézet, Szeged \\ ${ }^{2}$ Szegedi Tudományegyetem, Általános Orvostudományi Kar, Reumatológiai és Immunológiai Klinika, Szeged \\ ${ }^{3}$ Szegedi Tudományegyetem, Általános Orvostudományi Kar, Onkoterápiás Klinika, Szeged \\ ${ }^{4}$ Szegedi Tudományegyetem, Általános Orvostudományi Kar, Orvosi Genetikai Intézet, Szeged \\ ${ }^{5}$ Szegedi Tudományegyetem, Általános Orvostudományi Kar, Sebészeti Klinika, Szeged \\ ${ }^{6}$ Department of Medical Oncology, Dana-Farber Cancer Institute, Harvard Medical School, Boston, \\ MA, Amerikai Egyesült Államok
}

Kolléganönk emlékének ajánljuk dolgozatunkat.

\begin{abstract}
A Li-Fraumeni-szindróma autoszomális dominánsan öröklődő, többszörös daganatokra prediszponáló megbetegedés, melyet a TP53- (vagy CHEK2-) gén csírasejtvonalában bekövetkezett mutáció okoz. Munkánkban egy Li-Fraumeni-szindrómás család esetét mutatjuk be. Egy panaszmentes, 40 éves nőbetegnél bal felső lobectomiával primer pulmonalis leiomyosarcoma (T3N0), jobb felső lebeny 2. segmentectomia során adenocarcinoma (TlaN0), illetve a jobb középlebenyból ékreszekció során gyulladásos myofibroblastos tumor igazolódott. A beteg adjuváns terápiában nem részesült. 20 hónap múlva retroperitonealis liposarcoma eltávolítása történt, melyet adjuváns kemoterápia követett, azonban a kezelés ellenére a beteg rövidesen elhunyt. Időközben a felmerülő Li-Fraumeni-szindróma miatt a betegnél, lány- és fiúgyermekénél, valamint férfitestvérénél perifériás vérből izolált genomi DNS-mintán molekuláris genetikai vizsgálat történt a TP53-gén-mutációk elemzésére, amely az anyánál és fiúgyermekénél misszensz mutációt igazolt heterozigóta formában (c.722C>G p.Ser24lCys). Három évvel az anya halála után a 17 éves fiánál $3,5 \mathrm{~cm}$ osteosarcomát távolítottak el a jobb 2. borda elülső ívéről. Adjuváns kemoterápia ellenére a fiú 2 év múlva elhunyt. Négy generációt vizsgálva, a beteg nyolc családtagjánál 10 esetben fordult elő malignus tumor (gyomor-, emlő-, vastagbél-, 2 tüdőcarcinoma, leukaemia, leiomyosarcoma, liposarcoma és 2 osteosarcoma). A családtagok átlagéletkora 43,2 év (13-70 év) volt. A primer pulmonalis leiomyosarcoma, a gyulladásos myofibroblastos tumor, valamint az adenocarcinoma szinkrón megjelenése egy szervben extrém ritka. Amennyiben lehetséges, az elváltozások sebészeti reszekciója a választandó kezelési eljárás. A Li-Fraumeni-szindróma gyanújának megerősítéséhez genetikai vizsgálat - TP53-gén-mutáció-analízis - szükséges, illetve a család genetikai és klinikai szúrése javasolt. A betegség prognózisa rendkívül kedvezőtlen.
\end{abstract}

Orv Hetil. 2019; 160(6): 228-234.

Kulcsszavak: Li-Fraumeni-szindróma, p53 csírasejtvonal-beli mutáció, multiplex primer daganatok, osteosarcoma

\section{Li-Fraumeni syndrome}

$\mathrm{Li}$-Fraumeni syndrome is a rare genetic disorder predisposing the individual to multiple different cancer types, caused by a germline mutation of the TP53 or CHEK2 genes inherited in an autosomal dominant manner. We hereby describe the case of a family with $\mathrm{Li}$-Fraumeni syndrome. An asymptomatic 40 -year-old female was diagnosed with primary lung leiomyosarcoma (T3N0), adenocarcinoma (TlaN0), and inflammatory myofibroblastic tumor, which were surgically removed without further treatment. Twenty months later she underwent surgery for retroperitoneal liposarcoma and even though she received adjuvant chemotherapy, deceased shortly after. Due to family history, the patient underwent TP53 mutation testing, using peripheral blood genomic DNA, which identified a heterozygous, likely pathogenic missense mutation (c.722C $>$ G p.Ser24lCys) in case of the mother and her son. Three years after the patient's death, her 17-year-old son was diagnosed with a $3.5 \mathrm{~cm}$ osteosarcoma of the right second rib, which was surgically removed, followed by adjuvant chemotherapy. However, despite treatment, he deceased after two years. Throughout four generations of the patient's family, 10 malignant tumors (stomach-, breast-, 2 lung-, and colon cancer, leukemia, leiomyosarcoma, liposarcoma and 2 osteosarcoma) were diagnosed with a mean age of 43.2 (13-70 years) years. The simultaneous appearance of primary lung leiomyosarcoma, inflammatory myofibroblastic tumor and 
adenocarcinoma in the same organ is extremely rare. When possible, surgical resection should be carried out. Genetic testing for TP53 is recommended when family history is suggestive of Li-Fraumeni syndrome. Prognosis remains poor.

Keywords: Li-Fraumeni syndrome, p53 germline mutation, multiplex primary tumors, osteosarcoma

Sejben A, Tiszlavicz L, Polyák K, Kovács L, Maráz A, Török D, Leprán Á, Ottlakán A, Furák J. [Li-Fraumeni syndrome]. Orv Hetil. 2019; 160(6): 228-234.

(Beérkezett: 2018. szeptember 2.; elfogadva: 2018. szeptember 21.)

\section{Rövidítések}

ALKI $=($ anaplastic lymphoma kinase-1) anaplasticus lymphoma-kináz-1; CT = (computed tomography) számítógépes tomográfia; EGFR = (epidermal growth factor receptor) az epidermális növekedési faktor receptora; EORTC = (European Organisation for Research and Treatment of Cancer) Európai Rákkutató és Terápiás Szervezet; LFS = Li-Fraumeni-szindró$\mathrm{ma} ; \mathrm{MRI}=$ (magnetic resonance imaging $)$ mágnesesrezonancia-képalkotás; PDGFRI $=$ (platelet-derived growth factor receptor inhibitor) a vérlemezke-eredetü növekedési faktor receptorának gátlója; PET $=$ (positron-emission tomography) pozitronemissziós tomográfa; PGD = preimplantációs genetikai diagnosztika; RTG $=$ röntgen; SMA $=($ smooth muscle ac tine) simaizomaktin; TTFl $=($ thyroid transcription factor- 1$)$ thyreoideatranszkripciós faktor-1; UH = ultrahang; VAMT = (video-assisted mini thoracotomy) videoasszisztált minithoracotomia; VEGFR = (vascular endothelial growth factor retardant) a vascularis endothelialis növekedési faktor gátlója

A Li-Fraumeni-szindróma (LFS) ritka, autoszomális domináns módon öröklődő betegség, melyet a TP53-gén csírasejtvonal-beli mutációi okoznak. Az állapotot elöször 1969-ben írták le, és két amerikai orvos, Frederick Li és Joseph Fraumeni után nevezték el [1]. Az érintett betegeknél már fiatalkorban malignus daganatok alakulnak ki, valamint igen magas a multiplex tumorok kialakulásának veszélye $[1,2]$. A Li-Fraumeni-szindróma klasszikus kritériumai a következők: 1. valamely családtagnál 45 éves kor előtt sarcoma alakul ki; 2 . valamely elsőfokú rokonnál 45 éves kor előtt bármilyen típusú malignus tumor jelentkezik; 3 . egyéb első- vagy másodfokú rokonnál 45 éves kor előtt malignus daganatos betegség alakul ki [2]. Felnőtteknél a leggyakoribb malignus elváltozások az emlőből, a csontokból, valamint a lágyrészekből indulnak ki [3,4]. Vizsgálatunkban két családtagot mutatunk be, akiknél a TP53-gén-mutáció következtében kialakuló malignus tumorok jelentkeztek.

\section{Esetbemutatás}

\section{Az anya}

A 40 éves, tünetmentes nőnél tüdő leiomyosarcomát, lepidicus adenocarcinomát és gyulladásos myofibroblastos tumort követően metakrón módon retroperitonealis pleiomorf liposarcoma alakult ki.

A 40 éves, korábban egészséges, kétgyermekes anyánál, tumoros családi anamnézissel, 2006-ban elvégzett rutinmellkasröntgenen, majd később mellkas-CT-n az 1. ábrán látható elváltozást találták.

A $6 \mathrm{~cm}$-es, multinodularis laesio eltávolítására bal oldali posterolateralis thoracotomiából bal felső lebenyi lobectomia történt bronchus- és arterioplasticával. A szövettani vizsgálat multifokális, pleiomorf, hipo- és hipercelluláris területeket is tartalmazó, magas mitotikus aktivitású daganatot írt le, peribronchialis, perivascularis, valamint interszticiális propagáció jeleivel. Az im-

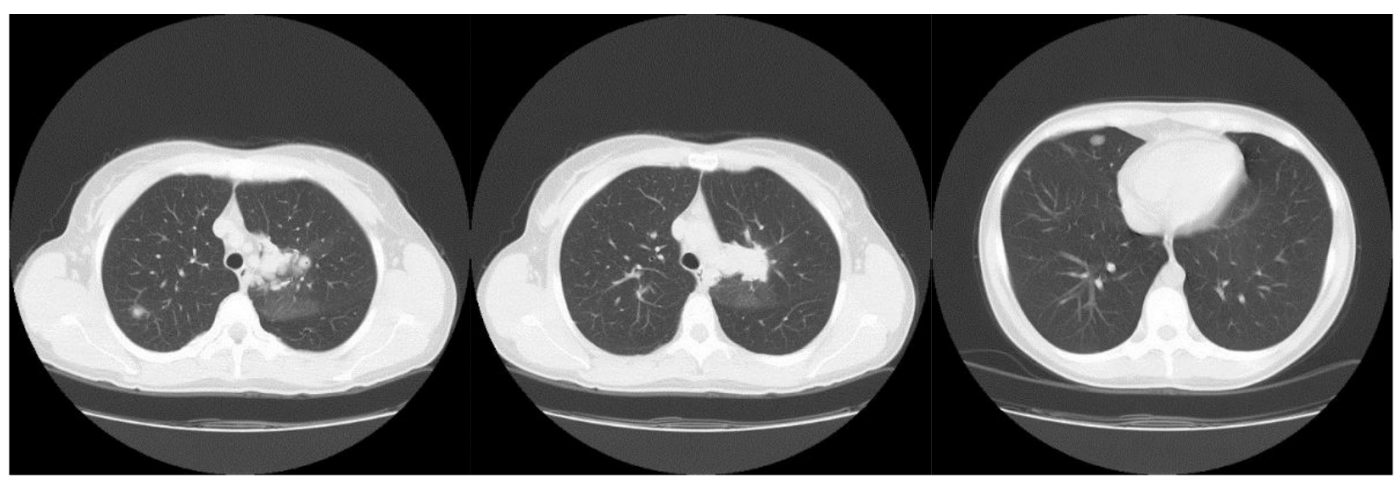

1. ábra $\mid$ Mellkas-CT: Jobb oldali kép: laesio a jobb felső tüdőlebenyben. Középső kép: laesio a bal felső tüdőlebenyben. Bal oldali kép: laesio a jobb középső tüdólebenyben 

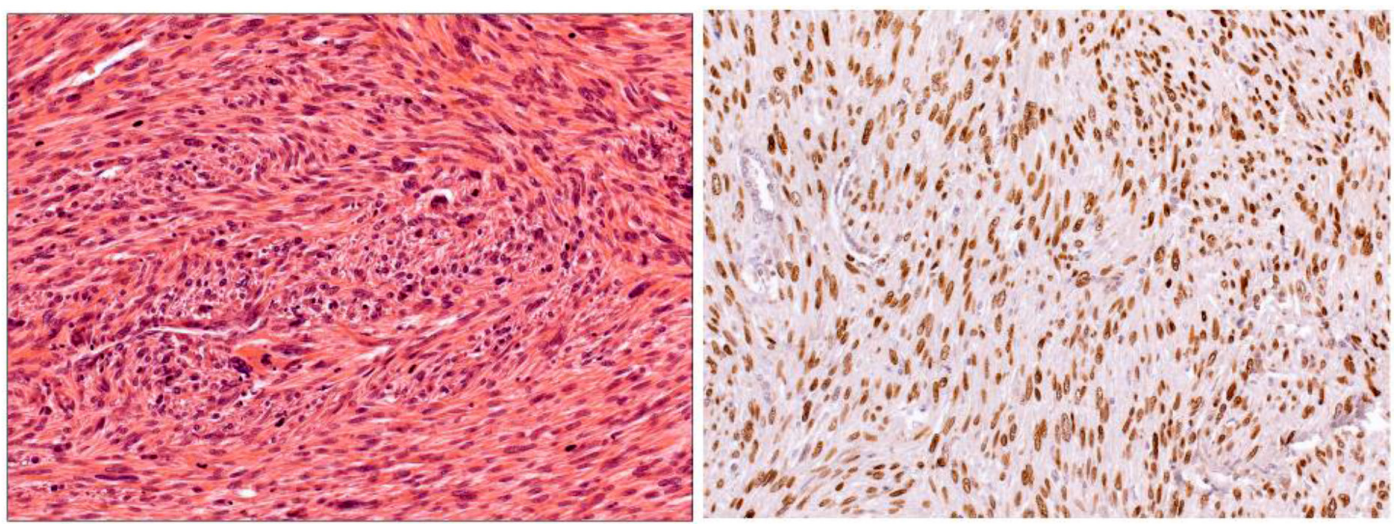

2. ábra

Bal oldal: bal felső tüdőlebeny reszekátuma (az anya kronológiailag első tumora): primer pulmonalis leiomyosarcoma, mely összefonódó kötegekbe rendeződött orsósejtekból áll $(\mathrm{He}, 20 \times$ ). Jobb oldal: a daganatsejtekben a p53-onkoprotein erós nukleáris pozitivitást mutat (immunhisztokémia, 20x)
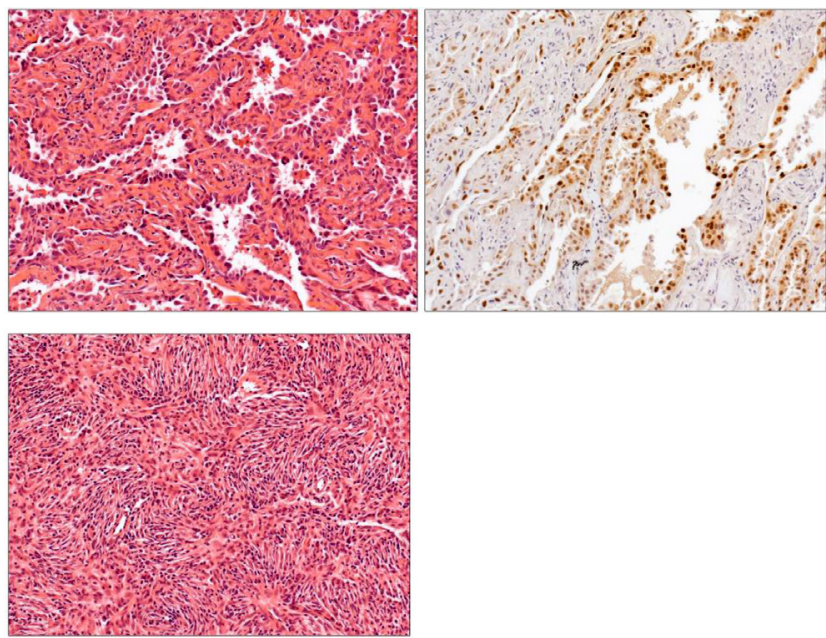

3. ábra

Jobb felső és középső tüdőlebeny (az anya második malignus tumora és benignus lágyrésztumora). Felső két kép: lepidicus adenocarcinoma részlete $(\mathrm{He}, 5 \times)$ és p53-onkoprotein-akkumuláció a tumorsejtekben (immunhisztokémia, 20x). Alsó kép: a tüdő gyulladásos myofibroblastos tumora $(\mathrm{He}, 20 \times)$

munhisztokémiai vizsgálat SMA (alfa-aktin)-, p53-, valamint dezminpozitivitást (2. ábra), illetve CD34-, CD117-, VEGFR-, EGFR- és cKIT-negativitást mutatott. A morfológiai megjelenés és az immunhisztokémi- ai vizsgálat pulmonalis leiomyosarcoma mellett szólt. A pleuralis és bronchialis felszínek tumormentesek voltak, valamint nyirokcsomóáttét sem igazolódott (pT3N0). Egy hónappal később jobb felső lebenyi 2. segmentectomia és középlebenyi ékreszekció történt minimálisan invazív módszerrel (video-assisted mini thoracotomy - VAMT). Az eltávolított felső tüdőlebenyi terime szövettani vizsgálata jól differenciált adenocarcinomát igazolt lepidicus predomináns mintázattal, centrálisan fibroticus területekkel (pTlaN0). Immunhisztokémiailag a daganat TTFl- és p53-pozitívnak bizonyult. Fokálisan EGFR-pozitivitás is jelen volt, részben a membránban, részben citoplazmatikusan. A végleges lelet primer, lepidicus adenocarcinomát véleményezett (TlaN0). A jobb középső tüdőlebenyben jól körülhatárolt sejtproliferáció mutatkozott, elágazódó myofibroblastszerű sejtekkel, néhány lymphocytával, plazmasejtekkel, makrofágokkal és mastocytákkal. Az immunhisztokémiai vizsgálat EGFR-, cKIT-, ALKl- és CD34-negativitást mutatott. Mindezek alapján diagnózisunk gyulladásos myofibroblastos tumor (gyulladásos pszeudotumor) lett (3. ábra). Mivel a primer leiomyosarcoma extrém ritkán fordul elő, metasztázisok kizárása céljából a beteg nőgyógyászati szakvizsgálaton esett át. A miometriumban talált jól körülhatárolt laesio miatt a

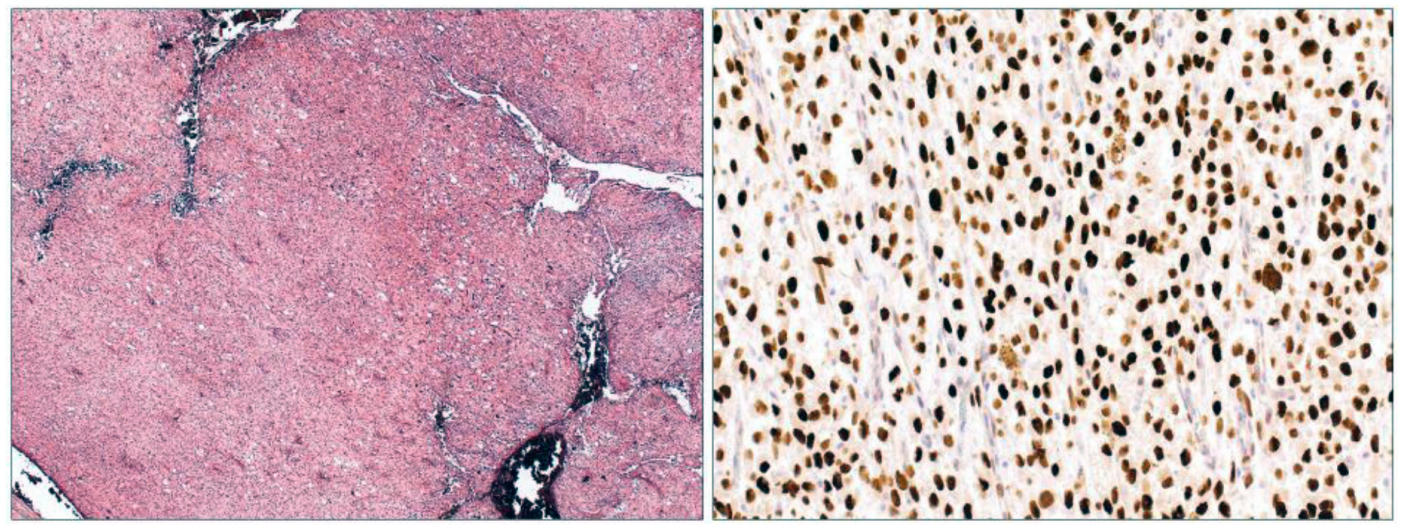

4. ábra

Bal oldal: retroperitonealis reszekátum (harmadik malignus tumor). A pleiomorf liposarcoma átnézeti képe (He, $5 \times$ ). Jobb oldal: p53 protein onkoprotein akkumuláció (immunhisztokémia, 20× ) 
beteg profilaktikus hysterectomián és jobb oldali adnexectomián esett át. Az eltávolított laesióban mikroszkóposan sem megnövekedett mitotikus aktivitás, sem citológiai atípia nem volt jelen. Méhleiomyoma igazolódott, mely semmilyen kapcsolatban nem állt a tüdőben lévő leiomyosarcomával.

Egy év múlva, a retroperitoneum jobb oldaláról egy $30 \times 32 \times 45$ mm-es elváltozást távolítottak el. A tumorban magas mitotikus aktivitású, myxoid, pleiomorf, atípusos zsírsejtekből felépülő daganat volt látható. A tumorban sok savanyú mukopoliszaharidot (PAS-AK, pH $2,5)$ lehetett kimutatni. Immunhisztokémiailag vimentin- és S100-pozitivitást, CK-KLl-, CDl0-, Melan-A-, HMB45-, dezmin- és CD34-negativitást detektáltunk. A harmadik, metakrón elváltozás pleiomorf liposarcomának bizonyult (4. ábra). Az adjuváns terápia ellenére a beteg 2007-ben elhunyt.

\section{A fiugyermek}

Tizenhét éves fiú, mellkasfali osteosarcomával.

Az anya 17 éves fiánál 2010-ben a jobb 2. bordában lévő, $26 \times 33 \times 34 \mathrm{~mm}$-es tumor miatt történt mellkasfal-reszekció (5. ábra). A szövettani feldolgozás osteoidot termelő, sarcomatosus sejtproliferációt igazolt szekunder kalcifikációval és részleges porcos differenciálódással. A tumor a mellkasfali izomzatot, valamint a környező lágyrészeket is infiltrálta. Az immunhisztokémiai vizsgálat SMA-pozitivitást, valamint CD34-negativitást mutatott, ami alátámasztotta a 'high-grade' osteosarcoma diagnózisát. Emellett p53-onkoprotein-akkumulációt és magas mitotikus proliferációs rátát (Ki-67) észleltünk (6. ábra). A lokálisan recidiváló, $6 \mathrm{~cm}$-es tumort 2011-ben re-reszekálták. A tumor ekkorra már a pleurát és a tüdőt is infiltrálta. Az immunhisztokémiai vizsgálat megerősítette a recidív tumor eredetét. Az adjuváns kemoterápia ellenére a beteg 2 évvel később elhunyt. Tekintettel arra, hogy a beteg családjában, négy generációt vizsgálva, nyolc családtagnál 10 esetben fordult elő malignus daganat, melyek a gyomrot, az emlőt, a vastagbelet, a tüdőt, a csontvelőt, a csontot, valamint a lágyrésze-

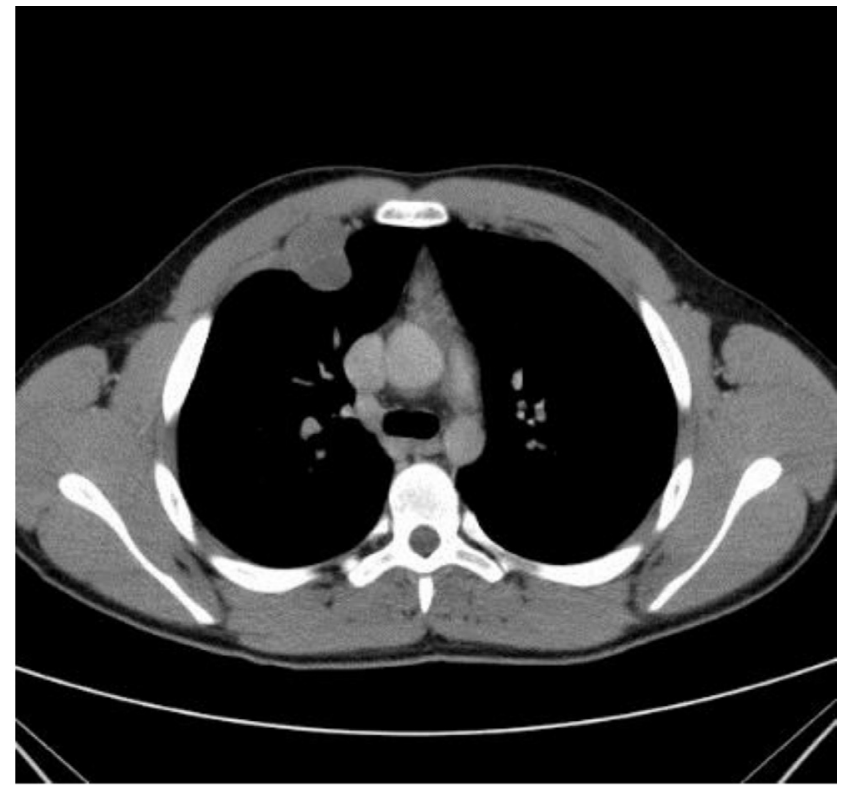

5. ábra | Mellkas-CT: térfoglaló folyamat a jobb 2. borda elülső ívén

ket érintették, genetikai vizsgálat történt a felmerülő Li-Fraumeni-szindróma esetleges igazolására. Az említett családtagok átlagéletkora 43,2 év (13-70 év) volt.

\section{Genetikai vizsgálat}

A probandánál, vagyis a beteg anyánál (III/2) a Li-Fraumeni-szindróma hátterében álló TP53-gén (17p13.1) kódoló szakaszainak és az azokat határoló nem kódoló régióknak a direkt szekvenálása történt perifériás vérből izolált genomi DNS-mintán (Department of Medical Oncology, Dana-Farber Cancer Institute, Harvard Medical School, Boston, MA, Amerikai Egyesült Államok). A probandánál a betegség hátterében álló misszensz mutáció (c.722C>G p.Ser24lCys) igazolódott heterozigóta formában. Klinikailag érintett fiánál $(\mathrm{IV} / 2)$ a TP53gén mutációját igazoltuk. A probanda klinikailag tünetmentes fiútestvérénél (III/l) és szintén tünetmentes leányuknál $(\mathrm{IV} / \mathrm{l})$ a mutáció nem igazolódott (7. ábra).
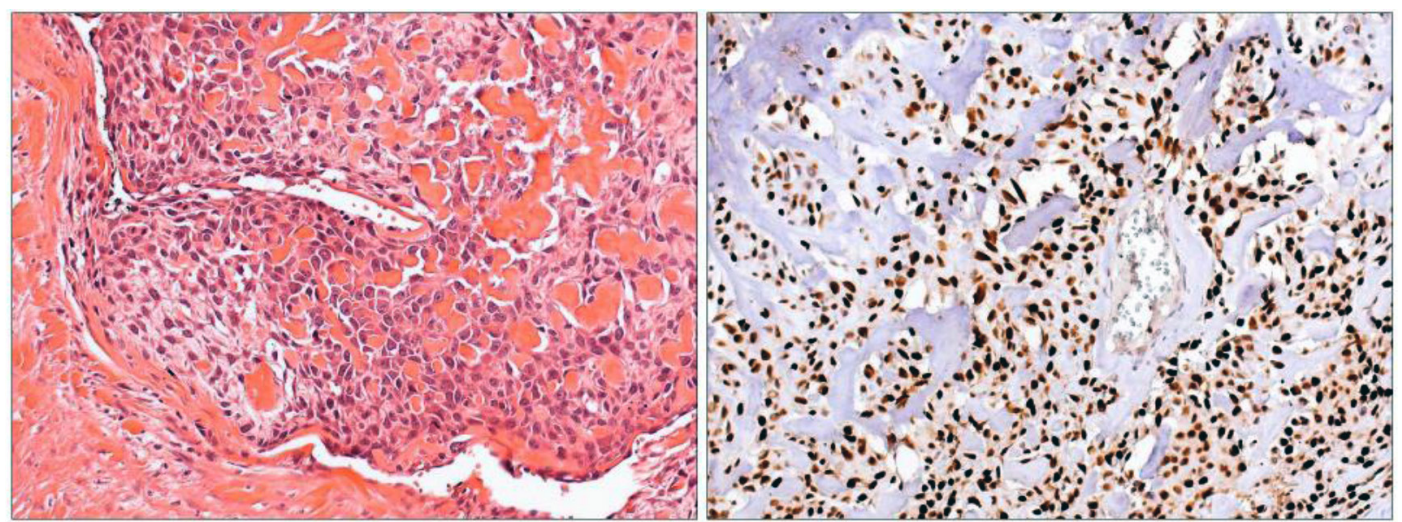

6. ábra $\quad$ A reszekált bordatumor (a fiúgyermek daganata) osteoidot termelő malignus sejtproliferációnak bizonyult. Bal oldal: az osteosarcoma széli részlete (He, 20×); jobb oldal: a tumor p53-pozitívnak bizonyult (immunhisztokémia, 20×) 
I.

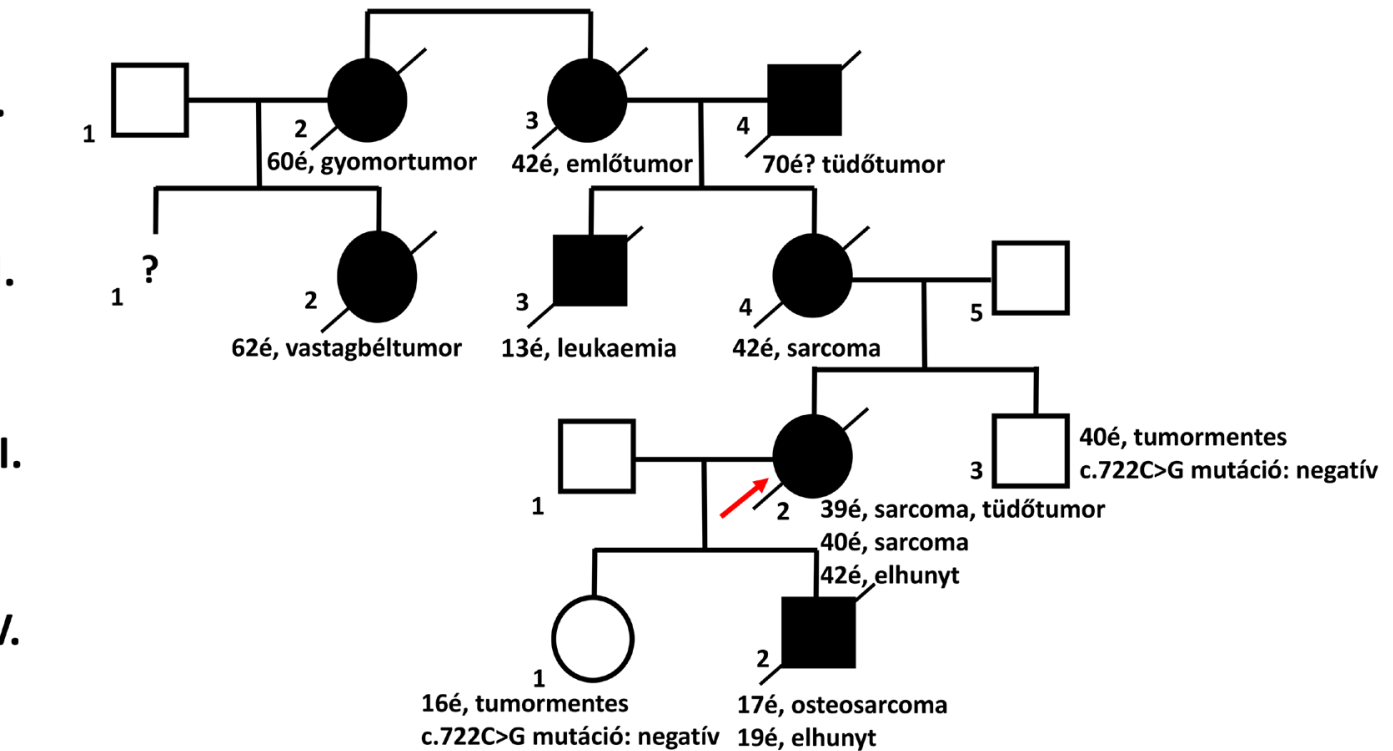

7. ábra

Li-Fraumeni-szindrómában szenvedő család. A probandánál (III/2, nyíl) és fiánál (IV/2) a betegség hátterében a TP53-génen csírasejtvonal-beli c.722C>G p.Ser241Cys mutáció igazolódott heterozigóta formában

\section{Megbeszélés}

A primer tüdősarcoma rendkívül ritka betegség, primer tüdőadenocarcinomával együttes előfordulását a nemzetközi irodalomban nem találtuk. A bemutatott családban előforduló malignus tumorok halmozódása miatt joggal gondoltunk a Li-Fraumeni-szindrómára, amelyet a genetikai vizsgálat is megerősített.

Azon családok esetében, ahol a klasszikus LFS kritériuma fennáll, 75\%-ban megtalálható a TP53 csírasejtvonal-beli genetikai defektus [5], és a kor elörehaladtával növekszik a tumoros elváltozások megjelenésének kockázata. Nők esetében 31, férfiaknál 46 éves korra 50\%-os elôfordulási valószínúséggel, míg 70 éves korban mindkét nemben 100\%-ban jelennek meg tumorok [6]. A Bougeard által közölt, 1730 francia LFS-beteget felölelő kohorszvizsgálat szerint a gyermekkorban megjelenő malignus elváltozás kumulatív incidenciája 5 éves korra 22\%-ra, míg a 18,7 év elérésekor 41\%-ra tehető [6-9].

A LFS-ás családok kezelésében és gondozásában optimálisan multidiszciplináris team múködik közre, melynek része a sebész és onkológus mellett patológus, radiológus, pszichológus, klinikai genetikus és nem utolsósorban családorvos.

Tekintettel arra, hogy a Li-Fraumeni-szindróma autoszomális dominánsan öröklődő kórkép, jellemző rá a változó expresszivitás, tehát a tünetek eltérő idópontokban jelennek meg, és különböző típusú daganatok fordulnak elő együttesen. Igazoltan TP53-mutációt hordozó beteg utódai nemtól függetlenül $50 \%$-ban öröklik a mutációt, vagyis $50 \%$-ban várható a korábban részletezett valószínúséggel a klinikai tünetek megjelenése.

Az érintett családok esetén felmerül - akár 18 éves kor előtt - a preszimptómás diagnosztika lehetősége, hiszen az igazoltan mutációt hordozó egyének rendszeres el- lenőrzése lehetőséget ad az elváltozások korai diagnosztizálására $[10,11]$.

A nemzetközi irodalom alapján az érintett családoknál alkalmazható a preimplantációs genetikai diagnosztika (PGD), amely lehetôvé teszi az embrió beültetését megelőzően a családban előforduló mutáció célzott vizsgálatát $[12,13]$. Habár a malignus daganatok szürésének hasznosságát kimutatták, a p53-gén mutációja esetén jelenleg még nem egyértelmúen effektív; számos TP53mutációhoz kapcsolódó daganatos elváltozás lefolyása során látható egy tünetmentes fázis, melyben korai stádiumban szürhetó ki a betegség, így javítva a terápia hatásosságát [14]. Sarcoma esetén a tünetmentes időszakban végzett szűrés, sebészi és onkológiai kezelés hosszabb túlélést eredményez. Más tumoroknál a szưrés eredménye nem ilyen egyértelmû́ [14]. A LFS-ás betegeknél kézenfekvő lenne a PET-CT rutinszerü alkalmazása szűrés céljára [15], amellyel 10-20\%-ban igazolhatók malignus tumorok. Azonban a PET-CT alatti sugárterhelés miatt, illetve azért, mert ezzel a módszerrel eddig csak előrehaladottabb daganatokat tudtak igazolni, az MRI-vel történő rutinszerú szűrést támogatja [15]. A nemzetközi szûrési protokoll [16] szerint génmutációt hordozó egyéneknél, gyermek- (1. táblázat) és felnőttkorban (2. táblázat) a táblázatokban részletezett vizsgálatok javasoltak.

A teljestest-MRI-szűrővizsgálattal a tünetmentes esetek 13\%-ában igazolódott malignus daganat [15]. A gyermekkori szűrésre alkalmazott teljestest-MRI-t szervspecifikus vizsgálatokkal is kiegészítik [6] (1. táblázat).

Amennyiben lehetséges, a Li-Fraumeni-szindrómában előforduló daganatok agresszív sebészi kezelése javasolt, amit indokolt esetekben onkológiai kezeléssel kell kiegészíteni. Ez bemutatott eseteinkben is megtörtént, azon- 


\begin{tabular}{llcll}
\hline & Általános kivizsgálás & ACC (adrenocorticalis carcinoma) & Agytumor & Lágyrész- és csontsarcoma \\
\hline Gyermek & - Teljes fizikális vizsgálat & - Hasi és kismedencei ultrahang & - Évenkénti agyi MRI & - Évenként teljestest-MRI \\
(18 éves korig) & 3-4 havonta & (UH) 3-4 havonta & (mágnesesrezonancia-kép- & (WBMRI) \\
& - Bármilyen panasz esetén & - Kóros UH-lelet esetén: 3-4 & alkotás); elsőre kontrasztos & \\
& azonnali megbeszélés a & havonta laborvizsgálat (totális & MRI, ha az elsó negatív, \\
& kezelőorvossal & tesztoszteron, dehidroepiand- & akkor a késóbbiekben natív & \\
& & roszteron-szulfát, androsztén- & MRI \\
& dion) & & \\
\hline
\end{tabular}

LFS = Li-Fraumeni-szindróma

2. táblázat |Ajánlott LFS-szúrési protokoll felnőtteknél

\begin{tabular}{|c|c|c|c|c|c|c|}
\hline & Általános kivizsgálás & Agytumor & $\begin{array}{l}\text { Lágyrész- és } \\
\text { csontsarcoma }\end{array}$ & Emlőtumor & $\begin{array}{l}\text { Gastrointestinalis } \\
\text { tumor }\end{array}$ & Melanoma \\
\hline Felnőtt & $\begin{array}{l}\text { - Teljes fizikális vizs- } \\
\text { gálat félévente } \\
\text { - Bármilyen panasz } \\
\text { esetén azonnali } \\
\text { megbeszélés a } \\
\text { kezelőorvossal }\end{array}$ & $\begin{array}{l}\text { (18 éves kor felett) } \\
\text { - Évenként agyi } \\
\text { MRI; elsőre } \\
\text { kontrasztos MRI, } \\
\text { ha az első negatív, } \\
\text { akkor a későbbiek- } \\
\text { ben natív MRI }\end{array}$ & $\begin{array}{l}\text { (18 éves kor felett) } \\
\text { - Évenkénti } \\
\text { kontrasztos } \\
\text { WBMRI } \\
\text { - Évenkénti hasi és } \\
\text { kismedencei UH }\end{array}$ & $\begin{array}{l}\text { - Emlőönvizsgálat } \\
\text { (18 éves kortól) } \\
\text { - Évente kétszer } \\
\text { orvosi emlővizsgá- } \\
\text { lat ( } 20 \text { éves } \\
\text { kortól) } \\
\text { - Évenként } \\
\text { emlö-MRI-szürés } \\
\text { (20-75 év) } \\
\text { - Kockázatcsökken- } \\
\text { tés céljából } \\
\text { bilateralis } \\
\text { mastectomia } \\
\text { mérlegelése }\end{array}$ & $\begin{array}{l}\text { (25 éves kor felett) } \\
-2-5 \text { évente felső } \\
\text { endoszkópia } \\
\text { + kolonoszkópia }\end{array}$ & $\begin{array}{l}\text { (18 éves kor felett) } \\
\text { - Évenként } \\
\text { bőrgyógyászati } \\
\text { vizsgálat }\end{array}$ \\
\hline
\end{tabular}

LFS = Li-Fraumeni-szindróma; MRI = mágnesesrezonancia-képalkotás; UH = ultrahang; WBMRI = teljestest-MRI

ban a tumorok genetikai háttere miatt a rosszindulatú daganatok máshol, illetve lokális recidívaként gyorsan és kiterjedten jelentek meg. A leiomyosarcomák azon előrehaladott eseteiben, amikor a preoperatív kemoterápiától az elsődleges elváltozás megkissebbítése és kedvezőbb reszekciós körülmények várhatók, doxorubicinifoszfamid kombinációval neoadjuváns kemoterápia javasolható [17]. A posztoperatív kemoterápia eredményei ellentmondásosak. A legtöbb vizsgálatban doxorubicinmonoterápiát vagy doxorubicinalapú kombinációkat alkalmaztak. Az EORTC nagy betegszámú tanulmányában nem volt haszna a posztoperatív kemoterápiának [18], azonban 18 adjuváns vizsgálat metaanalízisében a doxorubicinbázisú kezelés mind az 5 éves, mind pedig a teljes túlélés tekintetében előnyös volt [19]. Jelenleg nincs rutinajánlás, de $10 \mathrm{~cm}$-nél nagyobb, 'high-grade' tumorok vagy inkomplett reszekció esetén adjuváns kemoterápia javasolható $[17,20]$. A saját betegeinknél alkalmazott kemoterápiás kezelések sem bizonyultak érdemben sikeresnek. Az elörehaladott leiomyosarcomák elsődleges kezelési lehetősége évtizedeken át a doxorubicin- vagy ifoszfamidkemoterápia volt. Napjainkra a doxorubicin mellett alkalmazott olaratumab (plateletderived growth factor receptor inhibitor - PDGFRI) lett az egyik legperspektivikusabb kombináció, mely 11,8 hónappal növelte meg a teljes túlélést az önmagában al- kalmazott doxorubicinnel szemben [21]. A másodvonalbeli szerek közé tartozik a trabektedin [22], a pazopanib [23], az eribulin [24], illetve a gemcitabin-docetaxel [25]. Az utóbbi években egyre nagyobb hangsúlyt kap a precíziós medicina, amelyben a szövettani minták vagy akár a vérben keringő tumorsejtek genetikai elemzésével nyerhetünk információt a daganat kialakulásáért felelös hibás génekről, ahogyan eseteinknél is igazolódott a p53 tumorszuppresszor gén hibája, mely lágyrész- és osteosarcomákban igen gyakori mutáció [26]. Számos molekuláristerápia-alapú készítmény van jelenleg is fejlesztés és tesztelés alatt a mutáns p53 célzott, tumorellenes felhasználására [26], melyek jövőbeli alkalmazása sikeresebb kimenetelt eredményezhet a molekuláris célpont ismerete esetén.

\section{Következtetés}

A primer pulmonalis leiomyosarcoma extrém ritka malignus tumor. Adenocarcinomával, valamint más tumorokkal való együttes előfordulása felvetheti a Li-Fraumeni-szindróma lehetőségét. Hasonló esettel az irodalomban nem találkoztunk. Ezen daganatok elsődleges kezelése sebészi, amit lehetőség szerint onkológiai kezeléssel kell kiegészíteni. Részletes patológiai és genetikai vizsgálatok igazolhatják a 'germline' p53-mutációt, amely a 
rossz prognózisú Li-Fraumeni-szindróma genetikai megjelenését bizonyíthatja. A Li-Fraumeni-szindrómás családok tagjainak szürése a nemzetközi irodalom ajánlása szerint javasolt.

Anyagi támogatás: A szerzők anyagi támogatásban nem részesültek.

Szerzői munkamegosztás: S. A.: A cikk megírása, kutatómunka. T. L.: A kézirat lektorálása. P. K., K. L., L. Á.: Adatgyüjtés. M. A.: Az onkológiai rész lektorálása. T. D.: A genetikai rész lektorálása. O. A.: Adatgyújités, lektorálás. F. J.: Lektorálás, a cikk megírásának koordinálása. A cikk végleges változatát valamennyi szerző elolvasta és jóváhagyta.

\section{Érdekeltségek: A szerzőknek nincsenek érdekeltségeik.}

\section{Irodalom}

[1] Malkin D. Li-Fraumeni syndrome. Genes Cancer 2011; 2: 475484.

[2] Mann M, Asuncion C. Simultaneous primary lung sarcoma and carcinoma. J Surg Oncol. 1992; 49: 270-272.

[3] Li FP, Fraumeni JF Jr, Mulvihill JJ, et al. A cancer family syndrome in twenty-four kindreds. Cancer Res. 1988; 48: 53585362.

[4] Izawa N, Matsumoto S, Manabe J, et al. A Japanese patient with Li-Fraumeni syndrome who had nine primary malignancies associated with a germline mutation of the p53 tumor-suppressor gene. Int J Clin Oncol. 2008; 13: 78-82.

[5] Pathak S, Singh SR, Katiyar V, et al. Epidermal growth factor receptor-mutated lung cancer as the initial manifestation of germline TP53 mutation associated cancer. Cureus 2018; 10: e2395.

[6] O'Neill AF, Voss SD, Jagannathan JP, et al. Screening with whole-body magnetic resonance imaging in pediatric subjects with Li-Fraumeni syndrome: a single institution pilot study. Pediatr Blood Cancer 2018; 65: e26822.

[7] Guha T, Malkin D. Inherited TP53 mutations and the Li-Fraumeni syndrome. Cold Spring Harb Perspect Med. 2017; 7: a026187.

[8] Mai PL, Best AF, Peters JA, et al. Risks of first and subsequent cancers among TP53 mutation carriers in the National Cancer Institute Li-Fraumeni syndrome cohort. Cancer 2016; 122: 3673-3681

[9] Bougeard G, Renaux-Petel M, Flaman JM, et al. Revisiting LiFraumeni syndrome from TP53 mutation carriers. J Clin Oncol. 2015; 33: 2345-2352.

[10] Evans DG, Lunt P, Clancy T, et al. Childhood predictive genetic testing for Li-Fraumeni syndrome. Fam Cancer 2010; 9: 65-69.

[11] Lammens CR, Aaronson NK, Wagner A, et al. Genetic testing in Li-Fraumeni syndrome: uptake and psychosocial consequences. J Clin Oncol. 2010; 28: 3008-3014.

[12] Fresneau B, Brugières L, Caron $\mathrm{O}$, et al. Ethical issues in presymptomatic genetic testing for minors: a dilemma in Li-Frau meni syndrome. J Genet Couns. 2013; 22: 315-322.
[13] Rechitsky S, Verlinsky O, Chistokhina A, et al. Preimplantation genetic diagnosis for cancer predisposition. Reprod Biomed Online 2002; 5: 148-155.

[14] McBride KA, Ballinger ML, Killick E, et al. Li-Fraumeni syndrome: cancer risk assessment and clinical management. Rev Clin Oncol. 2014; 11: 260-271.

[15] Bojadzieva J, Amini B, Day SF, et al. Whole body magnetic resonance imaging (WB-MRI) and brain MRI baseline surveillance in TP53 germline mutation carriers: experience from the $\mathrm{Li}-$ Fraumeni Syndrome Education and Early Detection (LEAD) clinic. Fam Cancer 2018; 17: 287-294.

[16] Kratz CP, Achatz MI, Brugières L, et al. Cancer screening recommendations for individuals with $\mathrm{Li}$-Fraumeni syndrome. Clin Cancer Res. 2017; 23: e38-e45.

[17] Antman K, Crowley J, Balcerzak SP, et al. An intergroup phase III randomized study of doxorubicin and dacarbazine with or without ifosfamide and mesna in advanced soft tissue and bone sarcomas. J Clin Oncol. 1993; 11: 1276-1285.

[18] Woll PJ, Reichardt P, Le Cesne A, et al., EORTC Soft Tissue and Bone Sarcoma Group and the NCIC Clinical Trials Group Sarcoma Disease Site Committee. Adjuvant chemotherapy with doxorubicin, ifosfamide, and lenograstim for resected soft-tissue sarcoma (EORTC 62931): a multicentre randomised controlled trial. Lancet Oncol. 2012; 13: 1045-1054.

[19] Pervaiz N, Colterjohn N, Farrokhyar F, et al. A systematic metaanalysis of randomized controlled trials of adjuvant chemotherapy for localized resectable soft-tissue sarcoma. Cancer 2008; 113: 573-581.

[20] Rothermundt C, Fischer GF, Bauer S, et al. Pre- and postoperative chemotherapy in localized extremity soft tissue sarcoma: a European Organization for Research and Treatment of Cancer expert survey. Oncologist 2018; 23: 461-467.

[21] Tap WD, Jones RL, Van Tine BA, et al. Olaratumab and doxorubicin versus doxorubicin alone for treatment of soft-tissue sarcoma: an open-label phase $\mathrm{lb}$ and randomised phase 2 trial. Lancet 2016; 388: 488-497.

[22] Demetri GD, Chawla SP, von Mehren M, et al. Efficacy and safety of trabectedin in patients with advanced or metastatic liposarcoma or leiomyosarcoma after failure of prior anthracyclines and ifosfamide: results of a randomized phase II study of two different schedules. J Clin Oncol. 2009; 27: 4188-4196.

[23] van der Graaf WT, Blay JY, Chawla SP, et al. Pazopanib for metastatic soft-tissue sarcoma (PALETTE): a randomised, doubleblind, placebo-controlled phase 3 trial. Lancet 2012; 379: 18791886.

[24] Schöffski P, Chawla S, Maki RG, et al. Eribulin versus dacarbazine in previously treated patients with advanced liposarcoma or leiomyosarcoma: a randomised, open-label, multicentre, phase 3 trial. Lancet 2016; 387: 1629-1637.

[25] Seddon B, Strauss SJ, Whelan J, et al. Gemcitabine and docetaxel persus doxorubicin as first-line treatment in previously untreated advanced unresectable or metastatic soft-tissue sarcomas (GeDDiS): a randomised controlled phase 3 trial. Lancet Oncol. 2017; 18: 1397-1410

[26] Gao P, Seebacher NA, Hornicek F, et al. Advances in sarcoma gene mutations and therapeutic targets. Cancer Treat Rev. 2018; 62: 98-109.

(Furák József dr., Szeged, Semmelweis u. 8., 6720 e-mail: jfurak@gmail.com)

A cikk a Creative Commons Attribution 4.0 International License (https://creativecommons.org/licenses/by/4.0/) feltételei szerint publikált Open Access közlemény, melynek szellemében a cikk bármilyen médiumban szabadon felhasználható, megosztható és újraközölhetö, feltéve, hogy az eredeti szerző és a közlés helye, illetve a CC License linkje és az esetlegesen végrehajtott módositások feltüntetésre kerülnek. (SID_1) 